\title{
Convergent Innovation in Emerging Healthcare Technology Ecosystems: Addressing Complexity and Integration
}

\author{
Mark A. Phillips, Tomás S. Harrington, and Jagjit Singh Srai
}

(6)

\author{
Between the idea \\ And the reality \\ Between the motion \\ And the act \\ Falls the Shadow
}

T. S. Eliot (1888-1965)

Poet, dramatist, and literary critic

In The Hollow Men (1925)
?)

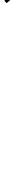

\begin{abstract}
Precision Medicine and Digital Health are emerging areas in healthcare, and they are underpinned by convergent or cross-industry innovation. However, convergence results in greater uncertainty and complexity in terms of technologies, value networks, and organization. There has been limited empirical research on emerging and convergent ecosystems, especially in addressing the issue of integration. This research identifies how organizations innovate in emerging and convergent ecosystems, specifically, how they address the challenge of integration. We base our research on empirical analyses using a series of longitudinal case studies employing a combination of case interviews, field observations, and documents. Our findings identify a need to embrace the complexity by adopting a variety of approaches that balance "credibility-seeking" and "advantage-seeking" behaviours, to navigate, negotiate, and nurture both the innovation and ecosystem, in addition to a combination of "analysis" and "synthesis" actions to manage aspects of integration. We contribute to the convergent innovation agenda and provide practical approaches for innovators in this domain.
\end{abstract}

\section{Introduction}

Precision Medicine and Digital Health are increasingly important areas that are reliant on "convergent" or "cross-industry" innovation (Sabatier et al. 2012; Thakur et al., 2012). A consequence of convergence is that it brings more uncertainty and allows greater influence from new knowledge and actors, including previously disparate technologies and capabilities (Rikkiev \& Mäkinen, 2013). In turn, there is an added complexity because convergence contradicts the two dominant forms of organizational learning, namely simplification and specialization (Levinthal \& March, 1993). This research focuses on the uncertainty and complex integration issues that arise from the emerging ecosystem, from developing the innovation and in forming a viable value network.
Much of the extant innovation literature has focused on innovation by incumbents in existing industries or with existing value-chain partners (Enkel \& Gassmann, 2010). More recently, there has been increasing interest in "cross-industry" or "convergent" innovation (Gassmann et al. 2010; Stieglitz, 2003). However, convergence can result in higher levels of equivocality, uncertainty, and risk as the diverse technology, alliance partners, and ecosystems merge (Enkel \& Heil, 2014; Hacklin, 2005; Mason et al., 2013). These considerations manifest themselves as different integration challenges that depend on the nature of the convergence (Rikkiev \& Mäkinen, 2013).

For convergence in healthcare technologies, apart from several practitioner articles (Eselius et al., 2008; Gupta et al., 2013; Mason et al., 2013), there are limited studies 


\title{
Convergent Innovation in Emerging Healthcare Technology Ecosystems
}

\author{
Mark A. Phillips, Tomás S. Harrington, and Jagjit Singh Srai
}

that examine the implications for technological or business model discontinuities (Bojovic et al., 2015; Sabatier et al., 2012) and these few (Bernabo et al., 2009; Dubé et al., 2014; Ramachandran et al., 2011; Shmulewitz et al., 2006) focus more on the phenomenon than on the implications.

Using empirical analyses in five longitudinal case studies with a combination of interviews, field observations (e.g., meetings and workshops), and documents, our exploratory research findings point to a need to embrace the complexity. We propose the adoption of approaches that balance taking "credibility-seeking" and "advantage-seeking" positions using non-ergodic routines that navigate, negotiate, and nurture with a combination of "analysis" and "synthesis" actions to manage integration.

\section{Theoretical Background}

\section{Addressing uncertainty and complexity}

Uncertainty and risk are inherent in innovation and arise from four types of complexity: evolutionary, temporal, relational, and cultural (Garud et al., 2013). Importantly, there are inherent differences between managing risks (with known probabilities) and uncertainty (or "unknown unknowns") (Teece et al., 2016). The major uncertainties and risks in innovation are generally considered to be technological, regulatory, and market based (Hobday, 1998), and they are typically addressed by a variety of mechanisms to "manage complexity", resulting in simplification and specialization (Levinthal \& March, 1993). However, such approaches create limitations and may inhibit the innovation itself (Garud et al., 2013). Although several of these challenges are acknowledged (Rikkiev \& Mäkinen, 2013), there has been limited empirical research to understand how they are addressed.

Differences between the nature of innovation and its impact have been considered in both the innovation literature (Abernathy \& Clark, 1985) and the diffusion literature (Rogers, 2003). In extant literature, there is more focus on the management of risk (Evanschitzky et al., 2012) than on addressing uncertainty, which is considered more likely and harder to manage (Teece et al., 2016).

In addressing uncertainty, McGrath (2001) confirms the earlier findings of March (1991) that the degree of exploration is important; broader searches across more variety can improve performance. The dynamic capab- ility literature points to the use of sensing, seizing, and transforming to better manage uncertainty (Teece et al., 2016), with abduction (as a mode of inference) being important to create new thinking for subsequent testing. This suggests creative abduction (Schurz, 2008) is more relevant (versus selective abduction, which chooses from multiple explanations), although creative abduction is rarely discussed in the literature (Prendinger \& Ishizuka, 2005).

Sommer and colleagues (2009) identify two approaches to respond to uncertainty: selectionism and trial-and-error. Selectionism refers to attempting many solutions in parallel and selecting the best based on the outcomes. However, such an approach can be costly and potentially inefficient. Trial-and-error learning refers to adjusting activities and targets as new information becomes available. The combination of complexity and uncertainty, and the need for creative and exploratory approaches using limited and often equivocal information, is counter to much of the traditional innovation literature with linear processes and defined decision criteria, as highlighted by Garud and colleagues (2013) and Bessant and colleagues (2005).

\section{Integration challenges}

Integration, by (re)combining knowledge, is inherent in innovation (Grant, 1996; Kogut \& Zander, 1993; Teece, 1996). As well as knowledge or technology integration, there is a need for market and organization integration (Tidd \& Bessant, 2013). Much of the "integration" literature focuses on intra-organization and cross-functional integration as Evanschitzky and colleagues (2012) identified in their meta-analysis of success factors in 233 innovation studies. Although integration (internal and external) has been identified as an indicator of innovation performance, it is moderated by equivocality (Koufteros et al. 2005). Yet, equivocality is itself inherent in convergence.

Alliance formation (Colombo et al., 2006; Eisenhardt \& Schoonhoven, 1996) and management under conditions of high uncertainty would, therefore, appear to be a critical capability for startups and new ventures within an incumbent firm. Previous literature has identified the need for a highly integrated value network as a key factor in performance (Prajogo \& Olhager, 2012), but this presupposes a strong understanding of the needs and capabilities of the alliance partners. In convergent innovation, ecosystems and value networks are emerging, so a comprehensive understanding may be lacking. 


\section{Convergent Innovation in Emerging Healthcare Technology Ecosystems}

\section{Mark A. Phillips, Tomás S. Harrington, and Jagjit Singh Srai}

Systems-integration risks are not new (for example, see Henderson \& Clark, 1990), but have traditionally been addressed by concepts such as modularity (Baldwin \& Clark, 1997; Schilling, 2000). However, the presumption in such an approach is that the knowledge is well codified (Cardinal et al., 2001). In convergence, this is more challenging, because such codification is initially limited.

What is less clear in the extant literature is how this complexity and integration is addressed. Garud and colleagues (2013) identified some challenges and resulting gaps in both research and practice, and they call for approaches that embrace the complexity as a "generative" process, rather than trying to simplify and "manage" it.

\section{Research Design}

This research aims to address these issues by considering the question of how organizations address the challenges of integration in convergent technology innovation within the wider context of convergent innovation for healthcare and medical technologies in emerging ecosystems.

Given the context of the enquiry, and the evolving nature of the setting, a qualitative approach was adopted (Yin, 2014). The design consisted of two main phases (see Figure 1). An exploratory phase involved 27 semi-structured interviews from a wide range of ecosystem stakeholders, which enabled better understanding of the emerging ecosystem itself (Table 1). The interviews were analyzed inductively using the Gioia (2012) method to identify "dimensions". From these dimensions and a review of innovation and ecosystem literature, an investigational tool was developed (using abduction) for use in the second phase. The second

Table 1. Ecosystem interviews to develop context and constraints

\begin{tabular}{ll}
\hline Data Sources & Details \\
\hline $\begin{array}{l}\text { Preliminary Ecosystem } \\
\text { Interviews }\end{array}$ & $\begin{array}{l}\text { 27 interviews of senior managers and } \\
\text { business leaders (including startups, } \\
\text { regulators, investors, technology } \\
\text { companies, government agencies, and } \\
\text { healthcare providers) }\end{array}$ \\
\hline
\end{tabular}

Further Ecosystem Interviews

12 interviews of 11 senior managers and business leaders (including startups, regulators, investors, technology companies, government agencies, and healthcare providers)

Observations

11 conferences (covering digital health, pharmaceutical, and medical technologies), meetings, and workshops

Academic, Business Press, 28 public documents and papers and Industry documents

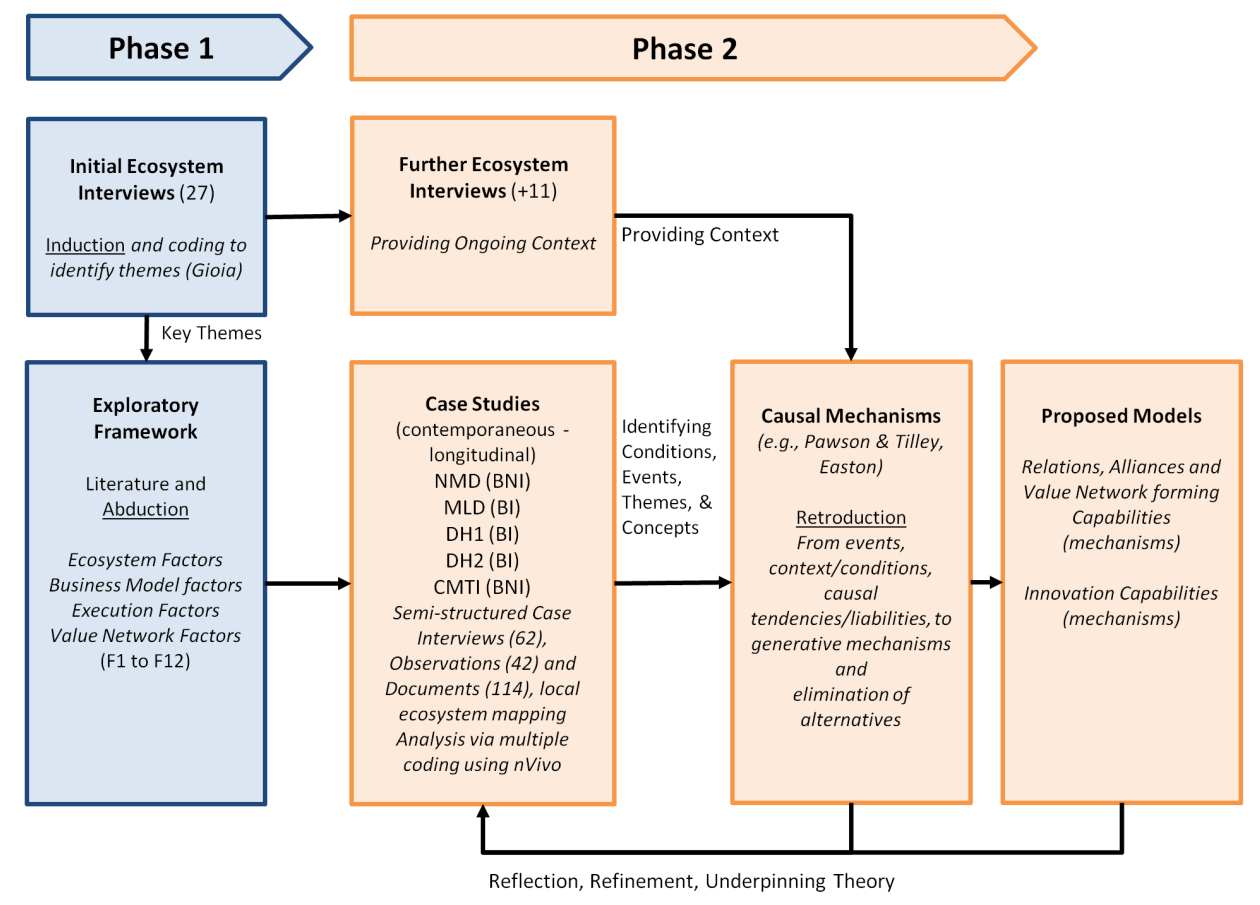

Figure 1. Overall research approach 


\section{Convergent Innovation in Emerging Healthcare Technology Ecosystems}

\section{Mark A. Phillips, Tomás S. Harrington, and Jagjit Singh Srai}

phase was based on empirical analyses of five in-depth longitudinal case studies conducted over 15- to 24month periods employing a combination of interviews, field observations, and primary documents (obtained under confidentiality) as data sources, together with supplementary evidence from public documents. The cases involved three established companies and two startups, with 62 case study interviews, 41 observations, and over 100 documents (see Table 2). Further ecosystem interviews were also conducted to provide contemporaneous context. The data were collected and analyzed using thematic and process coding to identify patterns. A further in-depth analysis based on Sayer's (1992) approach was then used to identify the potential underlying causal mechanisms using the ecosystem data as context (conditions and constraints).

\section{Findings}

The exploratory ecosystem interviews identified major issues for actors in understanding the ecosystem itself, the diverse perspectives of actors, and how to create and capture value. But the ecosystem not only creates "problems", it also provides "solutions" for innovators. There is therefore an explicit link between the ecosystem, the innovation, and capabilities needed.

All the cases provided evidence that organizations undertook activities to search and sense-make (and sensegive) in the emerging ecosystem. But the nature of those search and sense-making activities differed; those adopting a more exploratory and engaging approach, for example by snowballing (Goodman, 1961) to identify

Table 2. Case research sources

\begin{tabular}{|c|c|c|c|}
\hline Case & $\begin{array}{l}\text { Organization and Innovation } \\
\text { Description }\end{array}$ & $\begin{array}{l}\text { Examples and Numbers } \\
(\mathrm{N}=) \text { of Interviewees }\end{array}$ & $\begin{array}{l}\text { Number of Observations }(\mathrm{O}=) \text { and Private/Public } \\
\text { Documents }(\mathrm{D}=)\end{array}$ \\
\hline NMD & $\begin{array}{l}\text { New innovation unit in major } \\
\text { pharmaceutical/medical } \\
\text { technology company developing } \\
\text { a novel implantable medical } \\
\text { device }\end{array}$ & $\begin{array}{l}\text { R\&D Head, Scientific } \\
\text { Director, Head of Venture } \\
\text { Fund, Alliance Partners } \\
(\mathrm{N}=15)\end{array}$ & $\begin{array}{l}\text { - External workshops }(\mathrm{O}=1) \\
\text { - Business plan, board papers }(\mathrm{D}=31)\end{array}$ \\
\hline MLD & $\begin{array}{l}\text { Startup developing artificial } \\
\text { intelligence/machine learning } \\
\text { as a basis for screening, } \\
\text { diagnosis, and monitoring }\end{array}$ & $\begin{array}{l}\text { CEO, CTO, Medical } \\
\text { Director, investor, and } \\
\text { suppliers } \\
(\mathrm{N}=15)\end{array}$ & $\begin{array}{l}\text { - Board and technical meetings; meetings with } \\
\text { investors }(\mathrm{O}=16) \\
\text { - Business and development plans; technical } \\
\text { documents }(\mathrm{D}=25)\end{array}$ \\
\hline DH1 & $\begin{array}{l}\text { Innovation unit in large } \\
\text { healthcare provider developing } \\
\text { mobile and digital health } \\
\text { applications for a range of } \\
\text { medical conditions }\end{array}$ & $\begin{array}{l}\text { Managing Director, Project } \\
\text { Manager, board members, } \\
\text { and suppliers } \\
(\mathrm{N}=15)\end{array}$ & $\begin{array}{l}\text { - Team meetings; customer meetings; project } \\
\text { meetings }(\mathrm{O}=8) \\
\text { - Business plan and project review reports }(\mathrm{D}=26)\end{array}$ \\
\hline DH2 & $\begin{array}{l}\text { Startup developing wearable } \\
\text { and digital health solutions }\end{array}$ & $\begin{array}{l}\text { Chairman, } \mathrm{CEO}, \mathrm{CTO} \\
(\mathrm{N}=6)\end{array}$ & $\begin{array}{l}\text { - None }(\mathrm{O}=0) \\
\text { - Business plan; investment options }(\mathrm{D}=9)\end{array}$ \\
\hline CMTI & $\begin{array}{l}\text { Incubator developing } \\
\text { infrastructure and support for } \\
\text { convergent medical } \\
\text { technologies }\end{array}$ & $\begin{array}{l}\text { CEO, Business } \\
\text { Development Manager, } \\
\text { board members } \\
(\mathrm{N}=10)\end{array}$ & $\begin{array}{l}\text { - Company workshops and conferences; internal } \\
\text { review meetings }(\mathrm{O}=6) \\
\text { - Board paper; internal review papers }(\mathrm{D}=11)\end{array}$ \\
\hline
\end{tabular}




\title{
Convergent Innovation in Emerging Healthcare Technology Ecosystems
}

\author{
Mark A. Phillips, Tomás S. Harrington, and Jagjit Singh Srai
}

distant actors and then engaging them, appear to be more successful. The case findings point to extensive, repeated, and direct interactions as important for sense-making. Decision-making processes were largely informal (and invariably supported by external expertise), using directional criteria, and focused on key issues in terms of balancing value and risk.

Given the newness of the ecosystem, firms invested in activities that aided understanding and created credibility among potential partners, enabling them to engage, negotiate, and move to a position of advantage-seeking. However, these efforts were balanced by activities that continued to support or sustain the ecosystem itself, often with no immediate return, as described by the leader of one case (DH1): “...there needs to be 'congruence', a real alignment. Not just in terms of the outcome, but also cultural and how you are going to do it. Connections do not just happen - you need to 'cultivate' to create the right opportunities."

The uncertainty in the ecosystem presents issues, but is also a potential source of solutions. The casual mechanism analysis, derived from Sayer (1992), suggests organizations need to "navigate" the ecosystem, "negotiate" a position, and "nurture" the innovation by a combination of "credibility-seeking" and "advantage-seeking" activities that are "generative" in that they create opportunities. These activities appear to be underpinned by five interrelated processes or organizational routines: searching, sense-making, selecting, shaping, and sustaining. A series of findings and insights from our case studies are summarized in Table 3 . These activities and routines support four main objectives to shape the innovation and create value, to manage risks and the integration, and to develop the value network and wider ecosystem (Figure 2).

\section{Discussion and Implications for Practice}

The integration problem, as identified earlier, is complex and does not just include technological or market risk, but requires a simultaneous balancing of risk around four aspects: i) technical systems integration, ii) commercial or business models, iii) value network, and iv) organizational integration (O'Connor \& Rice, 2013).

\section{Technical systems and integration risks}

The bringing together of different scientific, technical, and industry knowledge inevitably adds a new dimension to the technical risk - that of technical systems integration. The cases highlighted several examples: Case NMD sought to integrate diverse science and technology from biology, micro-electronics, flexible electronics, new neural interfaces, energy harvesting (all at a much smaller scale than previously conceived), and new control algorithms. Similarly, Case MLD integrated visual cognition science with "millisecond scale" response monitoring on mobile technologies, cloud computing, and artificial intelligence (AI) technology.

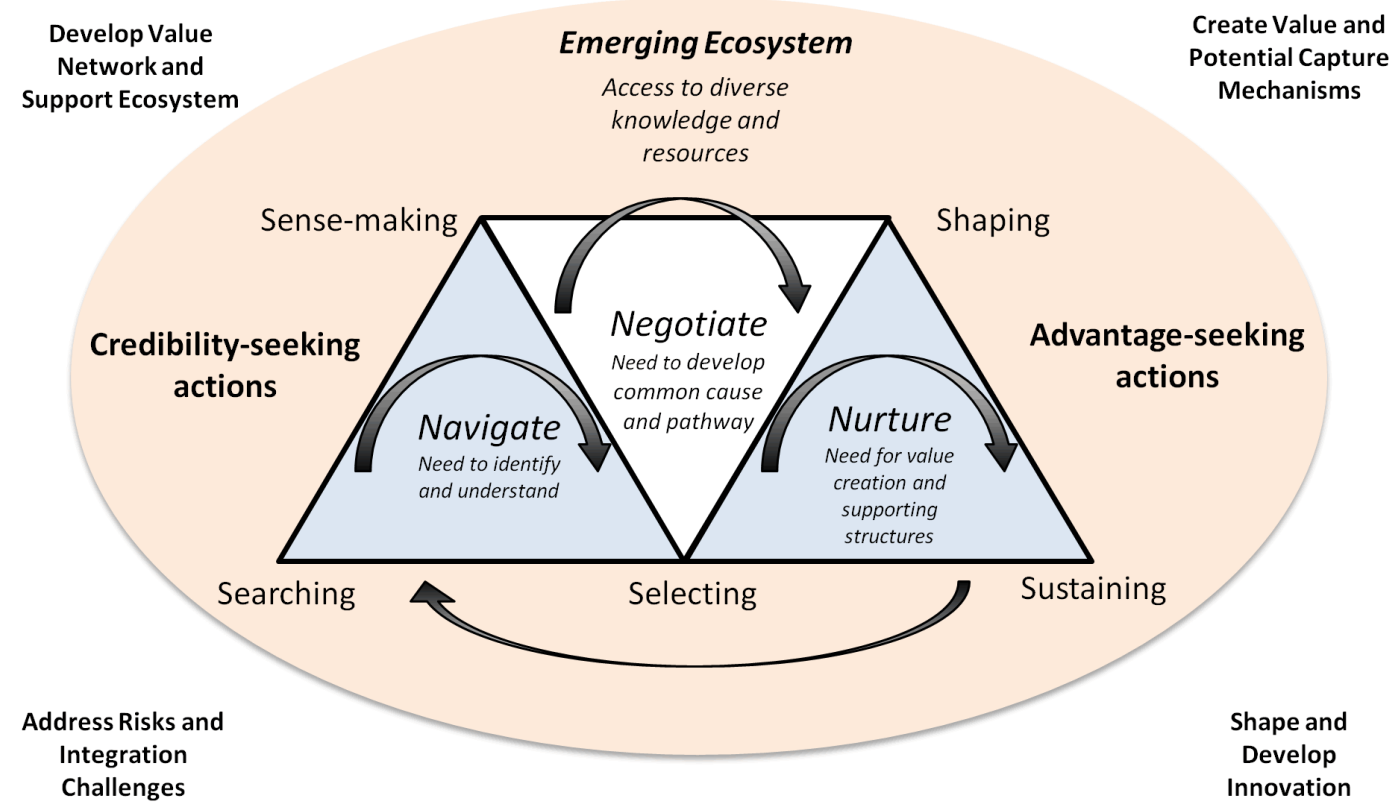

Figure 2. Proposed activity system model of convergent innovation 


\section{Convergent Innovation in Emerging Healthcare Technology Ecosystems}

\section{Mark A. Phillips, Tomás S. Harrington, and Jagjit Singh Srai}

Table 3. Example case findings and insights

\begin{tabular}{ll}
\hline Process & Example Case Evidence \\
\hline Searching & - "So,... it was structured to an extent. A bit like a structured \\
& fishing expedition. We tried many different ways."Case NMD \\
& - "We had the concept, but we didn't know anyone in the field \\
& {$[x x x]$ or anything related... So we sent cold call emails out to the } \\
& likely stakeholders.... and they introduced us to others."Case \\
& MLD
\end{tabular}

Insights

- Searches are often a combination of structured searching (of known domains) and (often) snowballing, using the network of your network to expand the search to new areas, but in a structured way to help address "distant" knowledge.

\begin{tabular}{ll}
\hline $\begin{array}{l}\text { Sense- } \\
\text { making } \\
\text { (and sense- }\end{array}$ & $\begin{array}{l}\text { "So it's like a bit like a deep dive in... and reflecting and then } \\
\text { giving) }\end{array}$ \\
& makesense of it..."Case NMD \\
& "...focused mainly on the value proposition, who the key \\
& stakeholders to help create 'pull."Case MLD \\
& - "To be honest, it's a bit like Brownian motion... forever moving \\
& around, bumping into different people. And you cannot predict \\
& beforehand whether they will add value or not.... and it might \\
& justbe timing or it doesn't fit their exact interest."Case MLD
\end{tabular}

- Sense-making (and giving) through developing "propositions" and wide engagement in ecosystem, often going beyond immediate contact and network to "test" the idea

- Involving the "unusual" suspects helps improve the sense-making process.

- The ability to connect and make sense depends not just on content, but on timing and mutual interest.

\footnotetext{
Selecting - "The hard choice is going to be - how much do we have a starting point that is much simpler and cruder than the ultimate goal, but while still maintaining a strategic differentiation from the [xxx] ind ustry of today?"Case NMD

- “... after the community identified the 'problem', we went out and consulted to confirm we had identified the right problem and decision criteria... and finally we checked that the community would be prepared to participate. So it was methodical, but it evolved."Case NMD

- So we knew that technologically it was different, that we'd need different criteria, and that things like safety data would be different to molecular medicine. So we'd also need to judge the portfolio using different criteria."Case NMD
}

- Selection often involves broad strategic aims rather than precise criteria and tries to balance making near-term progress against longer strategic aims.

- Engaging the ecosystem in defining success also helps to build confidence in the decision-making process.

- The decision is more about interpretation than process in an uncertain environment

Shaping - "We were a driver behind the concept... with people wondering why we are in this?... But people are now beginning to realize the potential. [Investment] represents a sort of transition... It's more than just developing technology."Case NMD

- "So, to start, we are probablygoing to position ourselves in 'convergence' as a 'Future Health Campus'... which is sort of pervasive."Case CMTI
- Innovators invest time in helping shape the ecosystem and create a compelling "vision" as well as driving the innovation itself.

- Shaping can be by influence rather than direct enactment.

\section{Sustaining}

- "So, you have to invest in relationships, and it consumes your resources. But back to our network: we are building it, we have the first few criticalones in place and then we are working through them, to see more."Case MLD

- "We have done something that is very distinct from other OI [open innovation] ventures..... So, we have said we will allow the winner to retain the IP [intellectual property], but with conditions: they must make it broadly accessible to the community. We [NMD] have the firstoption to license it to research and clinical use."Case NMD

- How can we find out who's key and engage them? Or which offering is most tractable? To reduce risk."Case MLD

- "We are well connected locally and continue to spend a lot of time networking. We are always making new connections.. More broadly we are connected to [nationalgroups] ... so, that gives us an opportunity to influence at a national level."Case $\mathrm{DH} 1$
- Investment is not just in the technology or innovation, but in the wider ecosystem, and in relationships.

- In order to sustain the innovation, risk reduction is critical and needs to be addressed early without losing sight of the long-term objective.

- Startups and SMEs are less likely to undertake major shaping activities, but they still need to invest in continuing to build connections access to ecosystem resources. 


\title{
Convergent Innovation in Emerging Healthcare Technology Ecosystems
}

\author{
Mark A. Phillips, Tomás S. Harrington, and Jagjit Singh Srai
}

To overcome these challenges, all the cases worked in a collaborative way with other knowledge and alliance partners, creating opportunities to understand and share. This finding suggests that the approach appears more dependent on building relationships, rather than on information codification (Tidd \& Bessant, 2013) and traditional technology integration approaches.

\section{Market and business model risk}

Convergent innovation, with increasingly digital content, provides opportunities for innovators to disrupt existing health and care pathways, making the identification of the value proposition and customer more complex and riskier. The nature of the technology used by Case MLD provided multiple options for business models, providing a "platform" from multiple revenue streams. Similarly, Case NMD identified several business models that might be appropriate depending on the success of the technology and its clinical application. However, such changes are not evident from the outset and do not appear to be readily designed, as they often emerge and evolve along with the innovation.

\section{Value network risk}

The prevalent approach from the cases was to first build transient partnerships. In doing so, the case firms developed knowledge and built relationships over time, thereby reducing risks. More robust relationships and long-term alliances were developed later. There is a 'trading off' of some short-term risk (by not having wellestablished networks) against making a "bad decision" on a longer-term partner. The alternative - to delay the formation of any partnerships and thus delay the innovation itself - was also observed in Case DH2, which ultimately was a failed venture.

\section{Internal organizational risks}

The risk of an innovation not being accepted by the incumbent organization is widely accepted in the literature (e.g., Danneels, 2011). To avoid resistance and mitigate organizational risk, the cases made multiple but small changes to existing routines. Examples of this approach were identified in Cases NMD, CMTI, and DH1.

\section{Summarizing approaches for addressing complexity and integration}

Risks arose from multiple sources: these risks could be considered in isolation, but they are interrelated. They form elements of a complex system, but rather than attempting to simplify the system, it is suggested that the complexity is more often addressed in a holistic way.
For example, Case MLD undertook multiple risk reviews, whereby, they address patient and user risks, technology risk, business model risks, and overall project management risks. Similarly, Case NMD took a systemic approach to managing risks, and having mapped the major risk areas at an early stage, they set about addressing those risks in multiple areas (including for example understanding the human biology, developing human-machine interfaces, developing new energy systems, and developing new ways to interpret novel data). The evidence suggests a move beyond the multiple risk approaches identified for disruptive innovation (e.g., Keizer \& Halman, 2007) to more comprehensive models as proposed by O'Connor and Rice (2013).

Despite knowing these represent categories of uncertainty that need to be addressed, it does not answer the core question - how? Revisiting the case evidence indicates several approaches being employed. Some are rooted in process, for example, in conducting formal risk assessments (as in Cases MLD and NMD) and making changes to processes to minimize or mitigate risk (as in cases NMD and DH1). Others aimed at building relations (evident in the Cases NMD, MLD, DH1, and CMTI, as previously discussed). Finally, there are cases that are more elusive and harder to classify, but are broadly based around management decisions and propensity to address wider ecosystem risks or in shaping the innovation "agency".

An early treatise on innovation by Usher (1966), revised from a book originally written in 1926, identifies two types of action that innovators may use: analytic (analysis) and synthesis. Analytic approaches can be conceived as using systematic methods to address largely anticipated or perceived gaps. Synthesis approaches are more creative and look to position the innovation to take advantage of future options. Revisiting the activity system suggested earlier (Figure 2), the underpinning routines may be conceived as being either largely analysis or largely synthesis driven by either a process, relational, or agency focus. This view suggests a conceptual model (Figure 3) that aims to position the integrating and risk management activities, in context, with the underlying approach.

This view also suggests approaches that are nondeterministic. Equally, they are not arbitrary, but nonergodic (Sydow et al., 2012). In such a complex ecosystem, it is unlikely that any previous state will be re-experienced and, hence, innovation approaches become more context sensitive. The challenge is in embracing 


\section{Convergent Innovation in Emerging Healthcare Technology Ecosystems}

\section{Mark A. Phillips, Tomás S. Harrington, and Jagjit Singh Srai}

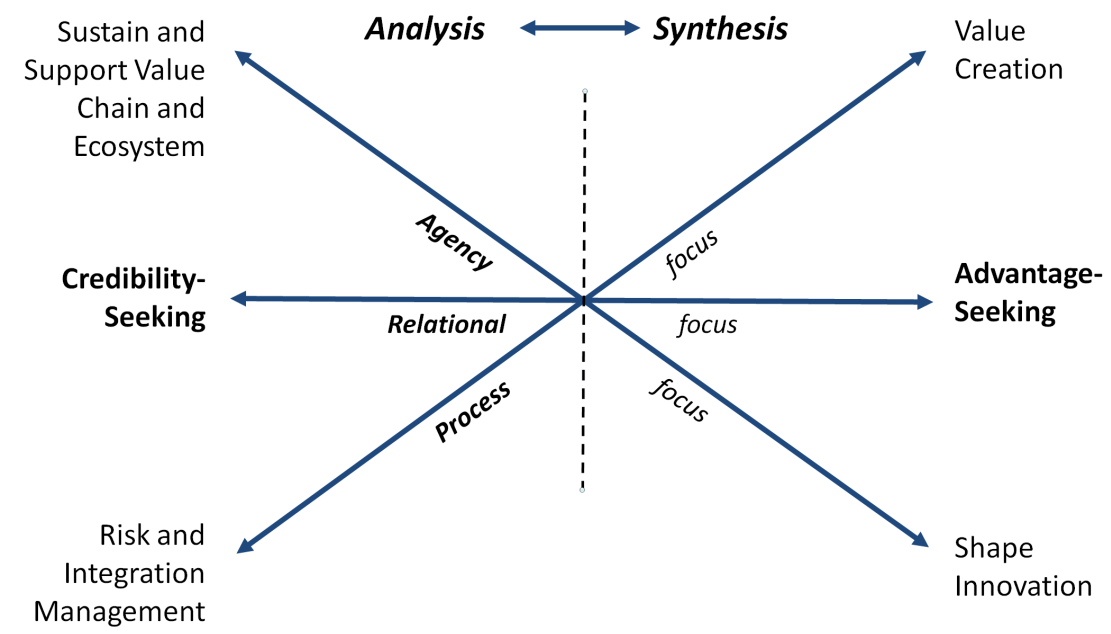

Figure 3. Integration of innovation activities

the complexity and managing the integration. Importantly, the innovator should not fixate too much on any one of the axes in Figure 3, but should look to "flex" between analytic and synthesis actions as needed and as opportunities arise.

There appears from the cases to be no single way of organizing, but they suggest a combination of activities and capabilities to access information and partners, to respond to technological, organizational, and ecosystem changes, and to maintain a focus on outcomes and performance. To quote one of the interviewees from Case DH2: “...convergence requires you to keep all those different parts synchronized. It's no good progressing one too fast... from a whisky perspective, we have someone called 'The Nose'. They are irreplaceable, they have an instinctive nose, to make it all work. It's not just science. But it's not art either. Convergence is somewhere on that spectrum."

\section{Conclusion}

The case evidence suggests innovators should undertake multiple engagements with diverse stakeholders as part of a search, sense-making, and selection process. Critically, this process can also help to create credibility and visibility within the ecosystem - necessary precursors to form alliances and create opportunities to achieve first-mover advantage. Innovators also have an opportunity to shape outcomes and their value network, but the importance of supporting and sustaining the emerging ecosystem is also identified here as a key activity.

Activities to sustain and support an innovation (or to shape it) are largely a result of management agency - to identify opportunities or challenges and then act to address them. The development of credibility, and later advantage-seeking positions, are the result of relational activities. The physical creation of value, integration, and the reduction of risk are primarily process driven. Actions to sustain, to seek credibility, and to reduce risk are effected by analytic approaches (analysis), in assessing the current state, developing options, and then deciding the best course. Finally, the value creation, advantage-seeking, and shaping activities are more about synthesis - identifying opportunities in patterns as they emerge.

This exploratory research addresses a relatively new phenomenon and so is limited to a few cases, therefore, limiting the generalizability. A qualitative approach was used, but despite significant observations and interviews, risk remains in inference and interviewee reliability. Our cases are focused on the United Kingdom but also involve partners from outside the UK. Although the cases are longitudinal, they were only studied for two years; however, they represent a formative part of the specific innovations and include major decisions or pivot points.

Future research would point to the need to better understand the emergence of such ecosystems and their impact on innovator processes in different contexts (e.g., different convergence regimes).

In summary, convergent innovation brings increased complexity and integration challenges that are not deterministic. There is a need to "embrace the complexity" by adopting a variety of approaches that balance credibility-seeking and advantage-seeking behaviours 


\title{
Convergent Innovation in Emerging Healthcare Technology Ecosystems
}

\author{
Mark A. Phillips, Tomás S. Harrington, and Jagjit Singh Srai
}

and oscillate between analysis and synthesis actions to address technological system, market, organizational, and value network integration risks. Although limited to a few cases in an emerging ecosystem, by taking a contemporaneous and longitudinal case approach, we address an identified gap in the literature on "how" organizations innovate in this context.

\section{Acknowledgments}

Funding for this research is provided by the Centre for Innovative Manufacturing in Continuous Crystallisation and Manufacturing (CMAC), which is funded by the Engineering and Physical Sciences Research Council (EPSRC).

This article was developed from a paper presented at the ISPIM Innovation Conference in Vienna, Austria, June 18-21, 2017. ISPIM (ispim-innovation.com) - the International Society for Professional Innovation Management - is a network of researchers, industrialists, consultants, and public bodies who share an interest in innovation management.

\section{About the Authors}

Mark A. Phillips is a Doctoral Researcher in the Institute of Manufacturing at the University of Cambridge, United Kingdom. His research focuses on innovation, emergent ecosystems, "convergence", and healthcare technologies. Before embarking on his PhD, Mark was a Senior Vice President and Head of Development, Supply and Service for diagnostics at GlaxoSmithKline. He held a variety of roles in a career spanning 30 years in pharmaceuticals and life sciences covering technical and engineering, manufacturing operations, global supply chain leadership, manufacturing strategy, lean and business change, and new business start-up. He has a first-class honours degree in Chemical Engineering from Loughborough University in the United Kingdom and a Masters in Manufacturing Leadership from Cambridge University, and he is a Chartered Engineer and a Fellow of the Institute of Chemical Engineers.
Tomás S. Harrington is Associate Professor of Digitalisation and Operations Management (Senior Lecturer) within the Innovation, Technology and Operations Management Group at Norwich Business School at the University of East Anglia (UEA) in the United Kingdom. Prior to joining the Faculty of Social Sciences at UEA in August 2017, Tomás spent eight years at the University of Cambridge's Institute for Manufacturing. His research and practice interests focus on industrial systems transformation, enabled by the adoption of advanced manufacturing and digital technologies. He has also held senior roles in industry encompassing new product development, process design, and big data analytics - most recently with Intel Corporation. Tomás holds Bachelor and $\mathrm{PhD}$ degrees in Chemistry and an MBA (with distinction) for which he received a Chartered Management Institute award in 2008.

Jagjit Singh Srai is Head of the Centre for International Manufacturing within the Institute for Manufacturing at the University of Cambridge, United Kingdom. His research focuses on the analysis, design, and operation of international production, supply and service networks, and the disruptive impacts of new technologies, markets, and regulations. As Research Director of Project Remedies, a $£ 23 \mathrm{~m}$ collaborative research programme involving leading pharmaceutical firms, applied research explores how new technologies may transform healthcare supply chains. Jag also advises leading multinationals, governments, and international institutions including UNCTAD, UNIDO, and WEF. Previous roles have been in industry with Unilever working as a Supply Chain Director of a multinational regional business, Technical Director of a national business, and other senior management positions. He holds a first-class honours degree in Chemical Engineering from Aston University, United Kingdom, and MPhil and PhD degrees in International Supply Networks from Cambridge University, and he is a Chartered Engineer and a Fellow of the Institute of Chemical Engineers. 


\section{Convergent Innovation in Emerging Healthcare Technology Ecosystems}

\section{Mark A. Phillips, Tomás S. Harrington, and Jagjit Singh Srai}

\section{References}

Abernathy, W. J., \& Clark, K. B. 1985. Innovation: Mapping the Winds of Creative Destruction. Research Policy, 14: 3-22.

https://doi.org/10.1016/0048-7333(85)90021-6

Baldwin, C. Y., \& Clark, K. B. 1997. Managing in an Age of Modularity. Harvard Business Review, 75(5): 84-93.

Bernabo, M., Garcia-Bassets, I., Gaines, L., Knauer, C., Lewis, A., Nguyen, L., \& Zolfaghari, L. 2009. Technological Convergence throughout the Eras: Part 3 - Biotechnology. Business Strategy Series, 10(1): 19-27.

https://doi.org/10.1108/17515630910937760

Bessant, J., Lamming, R., Noke, H., \& Phillips, W. 2005. Managing Innovation beyond the Steady State. Technovation, 25(12): 1366-1376.

https://doi.org/10.1016/j.technovation.2005.04.007

Bojovic, N., Rouault, S., \& Sabatier, V. 2015. What Innovative Business Models Can Be Triggered by Precision Medicine? Analogical Reasoning from the Magazine Industry. Innovation and Entrepreneurship in Health, 2: 81-94. https://doi.org/10.2147/IEH.S70108

Cardinal, L. B., Alessandri, T. M., \& Turner, S. F. 2001. Knowledge Codifiability, Resources, and Science-Based Innovation. Journal of Knowledge Management, 5(2): 195-204. https://doi.org/10.1108/13673270110393266

Colombo, M. G., Grilli, L., \& Piva, E. 2006. In Search of Complementary Assets: The Determinants of Alliance Formation of High-Tech Start-Ups. Research Policy, 35(8): 1166-1199. http://doi.org/10.1016/j.respol.2006.09.002

Danneels, E. 2011. Trying to Become a Different Type of Company: Dynamic Capability at Smith Corona. Strategic Management Journal, 32(1): 1-31.

http://dx.doi.org/10.1002/smj.863

Dubé, L., Jha, S., Faber, A., Struben, J., London, T., Mohapatra, A., Drager, N., Lannon, C., Joshi, P. K., \& McDermott, J. 2014 Convergent Innovation for Sustainable Economic Growth and Affordable Universal Health Care: Innovating the Way We Innovate. Annals of the New York Academy of Sciences, 1331(1): 119-141.

http://dx.doi.org/10.1111/nyas.12548

Eisenhardt, K. M., \& Schoonhoven, C. B. 1996. Resource-based View of Strategic Alliance Formation: Strategic and Social Effects in Entrepreneurial Firms. Organization Science, 7(2): 136-150. https://doi.org/10.1287/orsc.7.2.136

Enkel, E., \& Gassmann, O. 2010. Creative Imitation: Exploring the Case of Cross-Industry Innovation. $R \& D$ Management, 40(3): 256-270.

http://doi.org/10.1111/j.1467-9310.2010.00591.x

Enkel, E., \& Heil, S. 2014. Preparing for Distant Collaboration: Antecedents to Potential Absorptive Capacity in Cross-Industry Innovation. Technovation, 34(4): 242-260.

https://doi.org/10.1016/j.technovation.2014.01.010

Eselius, L., Nimmagadda, M., Kambil, A., Hisey, R. T., \& Rhodes, J. 2008. Managing Pathways to Convergence in the Life Sciences Industry. Journal of Business Strategy, 29(2): 31-42.

https://doi.org/10.1108/02756660810858134
Evanschitzky, H., Eisend, M., Calantone, R. J., \& Jiang, Y. 2012. Success Factors of Product Innovation: An Updated MetaAnalysis. Journal of Product Innovation Management, 29(S1): 21-37.

http://doi.org/10.1111/j.1540-5885.2012.00964.x

Garud, R., Tuertscher, P., \& Van de Ven, A. H. 2013. Perspectives on Innovation Processes. The Academy of Management Annals, 7(1): 775-819.

https://doi.org/10.1080/19416520.2013.791066

Gassmann, O., Zeschky, M., Wolff, T., \& Stahl, M. 2010. Crossing the Industry-Line: Breakthrough Innovation through Cross-Industry Alliances with 'Non-Suppliers'. Long Range Planning, 43(5-6): 639-654.

https://doi.org/10.1016/j.lrp.2010.06.003

Gioia, D. A., Corley, K. G., \& Hamilton, A. L. 2012. Seeking Qualitative Rigor in Inductive Research: Notes on the Gioia Methodology. Organizational Research Methods, 16(1): 15-31.

https://doi.org/10.1177/1094428112452151

Goodman, L. A. 1961. Snowball Sampling. The Annals of Mathematical Statistics, 32(1): 148-170. http://doi.org/10.1214/aoms/1177705148

Grant, R. M. 1996. Prospering in Dynamically-Competitive Environments: Organizational Capability as Knowledge Integration. Organization Science, 7(4): 375-387. https://doi.org/10.1287/orsc.7.4.375

Gupta, A., Schumacher, J., \& Sinha, S. 2013. Digital Health: A Way for Pharma Companies to Be More Relevant in Healthcare. New York: Booz \& Company.

Hacklin, F. 2005. Implications of Technological Convergence of Innovation Trajectories: The Case of the ICT Industry. International Journal of Innovation and Technology Management, 2(3): 313-330.

https://doi.org/10.1142/S0219877005000526

Henderson, R. M., \& Clark, K. B. 1990. Architectural Innovation: The Reconfiguration of Existing Product Technologies and the Failure of Established Firms. Administrative Science Quarterly, 35(1): 9-30. http://doi.org/10.2307/2393549

Hobday, M. 1998. Product Complexity, Innovation and Industrial Organisation. Research Policy, 26(6): 689-710. https://doi.org/10.1016/S0048-7333(97)00044-9

Keizer, J. A., \& Halman, J. I. M. 2007. Diagnosing Risk in Radical Innovation Projects. Research Technology Management, 50(5): 30-37.

Kogut, B., \& Zander, U. 1993. Knowledge of the Firm and the Evolutionary Theory of the Multinational Corporation. Journal of International Business Studies, 24(4): 625-645. https://doi.org/10.1057/palgrave.jibs.8490248

Koufteros, X., Vonderembse, M., \& Jayaram, J. 2005. Internal and External Integration for Product Development: The Contingency Effects of Uncertainty, Equivocality, and Platform Strategy. Decision Sciences, 36(1): 97-133.

http://doi.org/10.1111/j.1540-5915.2005.00067.x

Levinthal, D. A., \& March, J. G. 1993. Myopia of Learning. Strategic Management Journal, 14(52): 95-112.

http://doi.org/10.1002/smj.4250141009 


\section{Convergent Innovation in Emerging Healthcare Technology Ecosystems}

\section{Mark A. Phillips, Tomás S. Harrington, and Jagjit Singh Srai}

March, J. G. 1991. Exploration and Exploitation in Organizational Learning. Organization Science, 2(1): 71-88.

Mason, B., Bacher, G., Reynolds, H., \& Fraser, H. 2013. Collaborating beyond Traditional Boundaries: What Convergence Means for Our Health Care Systems. Somers, NY: IBM Global Business Services.

McGrath, R. G. 2001. Exploratory Learning, Innovative Capacity and Managerial Oversight. Academy of Management Journal, 44(1): 118-131.

http://doi.org/10.2307/3069340

O'Connor, G. C., \& Rice, M. P. 2013. A Comprehensive Model of Uncertainty Associated with Radical Innovation. Journal of Product Innovation Management, 30(S1): 2-18. http://doi.org/10.1111/jpim.12060

Prajogo, D., \& Olhager, J. 2012. Supply Chain Integration and Performance: The Effects of Long-Term Relationships, Information Technology and Sharing, and Logistics Integration. International Journal of Production Economics, 135(1): 514-522. https://doi.org/10.1016/j.ijpe.2011.09.001

Prendinger, H., \& Ishizuka, M. 2005. A Creative Abduction Approach to Scientific and Knowledge Discovery. Knowledge-Based Systems, 18(7): 321-326.

https://doi.org/10.1016/j.knosys.2004.12.003

Ramachandran, G., Wolf, S. M., Paradise, J., Kuzma, J., Hall, R., Kokkoli, E., \& Fatehi, L. 2011. Recommendations for Oversight of Nanobiotechnology: Dynamic Oversight for Complex and Convergent Technology. Journal of Nanoparticle Research, 13(4): 1345-1371. https://doi.org/10.1007/s11051-011-0233-2

Rikkiev, A., \& Mäkinen, S. J. 2013. Technology Convergence and Intercompany R\&D Collaboration: Across Business Ecosystems Boundaries. International Journal of Innovation and Technology Management, 10(4).

https://doi.org/10.1142/S0219877013500090.

Rogers, E. M. 2003. Diffusion of Innovations (5th ed.). New York: Free Press.

Sabatier, V., Craig-Kennard, A., \& Mangematin, V. 2012. When Technological Discontinuities and Disruptive Business Models Challenge Dominant Industry Logics: Insights from the Drugs Industry. Technological Forecasting and Social Change, 79(5): 949-962.

https://doi.org/10.1016/j.techfore.2011.12.007

Sayer, A. 1992. Method in Social Science: A Realist Approach (2nd Ed.). London: Routledge.

Schilling, A. 2000. Toward a General Modular System Theory and its Application to Interfirm Product Modularity. Academy of Management Journal, 25(2): 312-334. http://doi.org/10.5465/AMR.2000.3312918

Schurz, G. 2008. Patterns of Abduction. Synthese, 164(2): 201-234. https://doi.org/10.1007/s11229-007-9223-4
Shmulewitz, A., Langer, R., \& Patton, J. 2006. Convergence in Biomedical Technology Combination Products. Nature Biotechnology, 24(3): 277-280. http://doi.org/10.1038/nbt0306-277a

Sommer, S. C., Loch, C. H., \& Dong, J. 2009. Managing Complexity and Unforeseeable Uncertainty in Startup Companies: An Empirical Study. Organization Science, 20(1): 118-133. http://doi.org/10.1287/orsc.1080.0369

Stieglitz, N. 2003. Digital Dynamics and the Types of Industry Convergence: The Evolution of the Handheld Computers Market. In F. J. Christensen \& P. Maskell (Eds.), The Industrial Dynamics of the New Digital Economy: 179-208. London: Edward Elgar.

Sydow, J., Windeler, A., Müller-Seitz, G., \& Lange, K. 2012. Path Constitution Analysis: A Methodology for Understanding Path Dependence and Path Creation. BuR - Business Research, 5(2): 155-176. http://doi.org/10.1007/BF03342736

Teece, D. J. 1996. Firm Organization, Industrial Structure, and Technological Innovation. Journal of Economic Behavior and Organization, 31(2): 193-224. https://doi.org/10.1016/S0167-2681(96)00895-5

Teece, D., Peteraf, M., \& Leih, S. 2016. Dynamic Capabilities and Organizational Agility: Risk, Uncertainty, and Strategy in the Innovation Economy. California Management Review, 58(4): 13-36. https://doi.org/10.1525/cmr.2016.58.4.13

Thakur, R., Hsu, S. H. Y., \& Fontenot, G. 2012. Innovation in Healthcare: Issues and Future Trends. Journal of Business Research, 65(4): 562-569. https://doi.org/10.1016/j.jbusres.2011.02.022

Tidd, J., \& Bessant, J. 2013. Managing Innovation: Integrating Technological, Market and Organizational Change (5th Edition). Chichester, UK: John Wiley \& Sons.

Usher, A. P. 1966. A History of Mechanical Inventions. Cambridge, MA: Harvard University Press.

Yin, R. K. 2014. Case Study Research: Design and Methods (5th ed.). London: Sage Publications.

Citation: Phillips, M. A., Harrington, T. S., \& Srai, J. S. 2017. Convergent Innovation in Emerging Healthcare Technology Ecosystems: Addressing Complexity and Integration. Technology Innovation Management Review, 7(9): 44-54.

http://doi.org/10.22215/timreview/1105

Keywords: healthcare, convergent innovation, integration, complexity, ecosystems 